\title{
Habitat structure and small mammals abundances in one semiarid landscape in the Brazilian Caatinga
}

\author{
Rodrigo R. Freitas ${ }^{1}$, Pedro Luís B. da Rocha ${ }^{1} \&$ Paulo César Simões-Lopes ${ }^{2}$ \\ 1 Instituto de Biologia, Universidade Federal da Bahia. Campus de Ondina, 40170-000 Salvador, Bahia, Brasil. \\ E-mail:wiedomys@yahoo.com.br, peurocha@ufba.br \\ 2 Departamento de Ecologia e Zoologia, Universidade Federal de Santa Catarina. 88010-970 Florianópolis, Brasil. \\ E-mail: lamaqs/@ccb.ufsc.br
}

\begin{abstract}
Studies conducted under a major project sponsored by the Brazilian Academy of Sciences in the 1970's concluded that the small mammal fauna of the semiarid Caatinga region of Brazil is impoverished and highly restricted to mesic granite outcroppings due to the lack of water conserving physiological capabilities in its species. This work focuses the abundance of small mammals in five typical Caatinga habitats. Indirect gradient analysis shows that three theoretical environmental variables explain most of the variance present in the community abundance matrix. Direct analysis of gradients show that none of these variables is highly correlated to availability of granite outcroppings. Our data also suggest that the abundances in Caatinga are not particularly low when compared to neighbor biomes and that underlying factors of habitat use by Caatinga small mammals are more complex than previously supposed.

KEY WORDS. Adaptability, capture success, electivity, gradient analysis, richness.

RESUMO. Estrutura de habitat e abundância de pequenos mamíferos em uma paisagem semiárida da Caatinga brasileira. Estudos realizados dentro de um grande projeto financiado pela Academia Brasileira de Ciências na década de 1970 concluíram que a fauna de pequenos mamíferos da região semiárida da Caatinga do Brasil é empobrecida e altamente restrita a afloramentos graníticos mésicos devido à falta de capacidades fisiológicas para a conservação de água das suas espécies. Este trabalho enfoca a abundância de pequenos mamíferos em cinco habitats típicos da Caatinga. A análise indireta de gradiente mostra que três variáveis ambientais teóricas explicam a maior parte da variância presente na matriz de abundâncias da comunidade. $A$ análise direta de gradiente mostra que nenhuma dessas variáveis está altamente correlacionada à disponibilidade de afloramentos graníticos. Nossos dados também sugerem que a abundância na Caatinga não é particularmente baixa quando comparada a biomas vizinhos e que os fatores subjacentes ao uso do habitat pelos pequenos mamíferos da Caatinga é mais complexo do que previamente suposto.

PALAVRAS CHAVES. Adaptabilidade, análise de gradiente, eletividade, riqueza, sucesso de captura.
\end{abstract}

\begin{abstract}
Although the Brazilian Caatinga is one of the most important xeric morphoclimatic domains in South America, studies on the ecology of its vertebrates are scant. The results of a major project sponsored by the Brazilian Academy of Sciences in the 1970's based on mammals and reptiles concluded that the Caatinga harbors an impoverished fauna poor in endemic species (Mares et al. 1985, VANZOLIni et al. 1980). For mammals, the studies concluded that: (1) the geographic center of the Caatinga harbors a relatively impoverished small mammal fauna (STREILEIN 1982a); (b) small mammal species from Caatinga do not possess pronounced physiological capabilities for water conservation (STREILEIN 1982b) and most of them reproduce year round but with varying degrees of success (STREILIEN 1982c);
\end{abstract}

(c) most of the Caviomorpha rodents and marsupial species (but not the Sigmodontinae species) compensate for he lack of physiological capabilities for water conservation by showing affinity for the stable, mesic habitats provided by granite outcroppings (MARes et al. 1981, STREILEIN 1982d); (d) the distributional pattern of space use by small mammals seems to be maintained by their interspecific agonistic behavior repertoires (StReilein 1982e). It has been suggested that the irregular temporal pattern of rainfall, typical in Caatinga, has precluded directional selection leading to features adapted to aridity in short-lived mammals, and therefore animals now present in the biome are versatile species living in more mesic microhabitats (MAREs et al. 1985). 
This conclusion is nevertheless based either on systematic data collected for a limited range of Caatinga habitats or on scattered data collected for a broader range of habitats characterized only in a qualitative way.

Since then, increasing activity is the fields of taxonomy and systematics has started to show that the diversity and number of endemic species in areas of Caatinga may be higher than previously supposed (Oliveira et al. 2003). On the other hand, new data, although scanty, corroborate the idea that many species of small mammals inhabiting Caatinga habitats show only minor physiological adaptation for water conservation (Mendes et al. 2004, Ribeiro et al. 2004), relying on movements across the diverse microhabitats of Caatinga to survive water stress experienced in xeric moments. If this is the case, one single environmental gradient related to humidity should be able to explain most of the variance in small mammals abundances in Caatinga landscapes.

In order to test this prediction, the objectives of the present work are: (1) to quantitatively characterize the structure (substratum and plant cover) of the diverse habitats representative of the Caatinga landscape; (2) to detect environmental gradients correlated to the abundance of small mammal populations.

\section{MATERIAL AND METHODS}

\section{Study area}

The study was carried out in Curaçá ( $\left.8^{\circ} 59^{\prime} \mathrm{S}, 39^{\circ} 54^{\prime} \mathrm{W}\right)$, Bahia state (Fig. 1), between August 1998 and March 1999. This is one of the driest areas of Brazilian Caatinga (mean annual precipitation: $452 \mathrm{~mm}$ ) and local temperatures are high, ranging from 21.1 to $30.1^{\circ} \mathrm{C}$ (mean annual temperature: $24,9^{\circ} \mathrm{C}$ ). The rainy period in Curaçá goes from December (and sometimes from October) to March (Rizzinı 1979). The high seasonality in rainfall pattern leads to a sharp deciduousness in the flora of Caatinga in general and particularly in Curaçá. We have obtained data on monthly rainfall from 1997 to 1999 from the meteorological station of Logos-Butiá Company, $40 \mathrm{~km}$ apart from the most distant area sampled.

We have chosen one representative area in each of the five most typical habitats of Curaçá landscape in order to sample the habitat structure (soil and plant cover) and the small mammal communities. The names presented below are the local Brazilian names for the distinct habitats:

Serra (Fig. 2): small granitic mountains up to $300 \mathrm{~m}$ high quiet common in the Curaçá landscape. Serras (sometimes referred as "serrote", e.g. MAREs et al. 1985) has many natural refuges to the local fauna as well as water springs. The plant cover is dense, diverse and mainly arboreal.

Lajeiro (Fig. 3): flat granite layer with many loose rocks and fissures that are usually associated with cactaceans and euphorbiaceans and can be used as shelter by the smaller mammals. The plant cover is very sparse.

Tabuleiro (Fig. 4): area usually flat, covered with loose gravel, and containing scattered small granite outcroppings (not sampled) that enhance habitat heterogeneity. "Tabuleiro" (sometimes referred as "campos de matacões", e.g. Aв'sABER 1980) represents the most common natural habitat in Curaçá but it does not offer free water and shelter to small mammals. The plant cover is sparse and composed mainly by scrubs $2 \mathrm{~m}$ tall and cacti (Pilosocereus sp.), although individuals of "umbuzeiro" (Spondias tuberosa Arr. Cam.) can grow up to $5 \mathrm{~m}$ tall.

Baixio (Fig. 5): corresponds to the forested areas near some intermittent rivers that are less subject to flooding than the "várzea". Trees are usually around $3 \mathrm{~m}$ high and there is a conspicuous herbaceous stratum. In this study, the "baixio" near the river Riacho da Melancia was sampled. An incipient canopy is formed in places where the trees are denser and individuals as tall as $20 \mathrm{~m}$ (e.g. Tabebuia (Cham.) Standl.) are not uncommon. The terrain is quite sandy, flat, and the exposed roots of trees offer some places of shelter to the small sized fauna.

Várzea (Fig. 6): plains close to intermittent rivers that are subject to flooding during the rainy season and are common in the region of Middle São Francisco River. In this study, we have chosen the "várzea" of the river Riacho da Melancia. The local soil is composed basically of gray clay named "massapê". The local topography is flat and lacks obvious natural refuge to the small mammal fauna. The plant cover is composed mainly by sparse, low trees and patches of Jatropha mollissima Baill. ("pinhão") and Cnidoscolus phylacanthus Pax \& Hoff. ("favela"). Individuals of Tabebuia caraiba Murr ("caraibeira"), the tallest trees in the region (about $20 \mathrm{~m}$ tall), represent an exception for this pattern.

\section{SAMPLING STRATEGY}

\section{Small mammal communities}

In each chosen area of the five habitat categories we have set two distinct trap grids, $5 \mathrm{Km}$ apart, one between Aug/15/ 1998 and Nov/19/1998 (end of dry season) and one between Dec/19/1998 and Mar/02/1999 (raining season). Each grid had 112 live traps evenly spaced in lines and columns $20 \mathrm{~m}$ apart. In places where the branches of different trees touched each other, Sherman live traps were tied to the trunks $1,5 \mathrm{~m}$ above the ground. We used 45 Havahart traps, 25 Tomahawk traps, and 42 Sherman traps bated with banana smeared with peanuts butter by the morning and checked after 24 hours. Sampling effort per habitat per season was 1740 trap nights in the várzea and 1740 in the "serra" (the most different physiognomies), 333 in the "tabuleiro", 333 in the baixio, and 330 in the "lajeiro" (the last one sampled only in the dry season). Some individuals were painless killed in order to confirm specific determination, and their skulls and skins are kept in the mammal collection of the Ecology and Zoology Department of the Federal University of Santa Catarina, Brasil (UFSC): Caviidae, Galea spixii (Wagler, 1831): 2816, 2831; Didelphidae, Monodelphis domestica (Wagner 1842): 2818, Gracilinanus agilis (Burmeister, 1854): 2819; Echimyidae, Thrichomys apereoides (Lund, 1839): 2820, 2821; Muridae, Wiedomys pyrrhorhinos (Wied-Neuwied, 1821): 2822, $2823,2824,2825,2826,2827,28282,2829$. The mass of all small 
SOUTH AMERICA

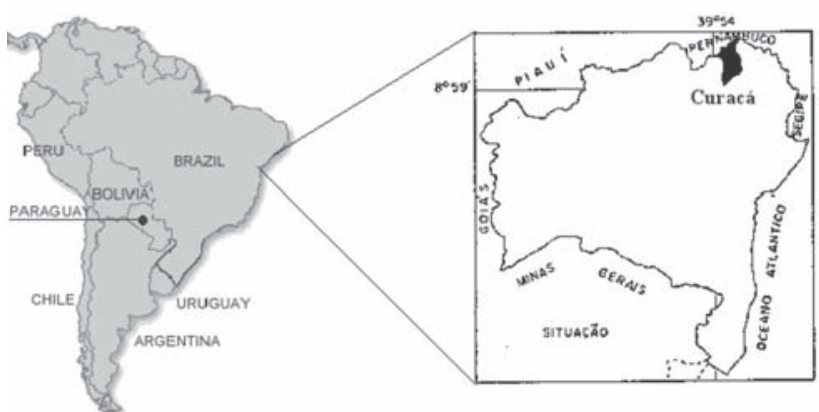

1
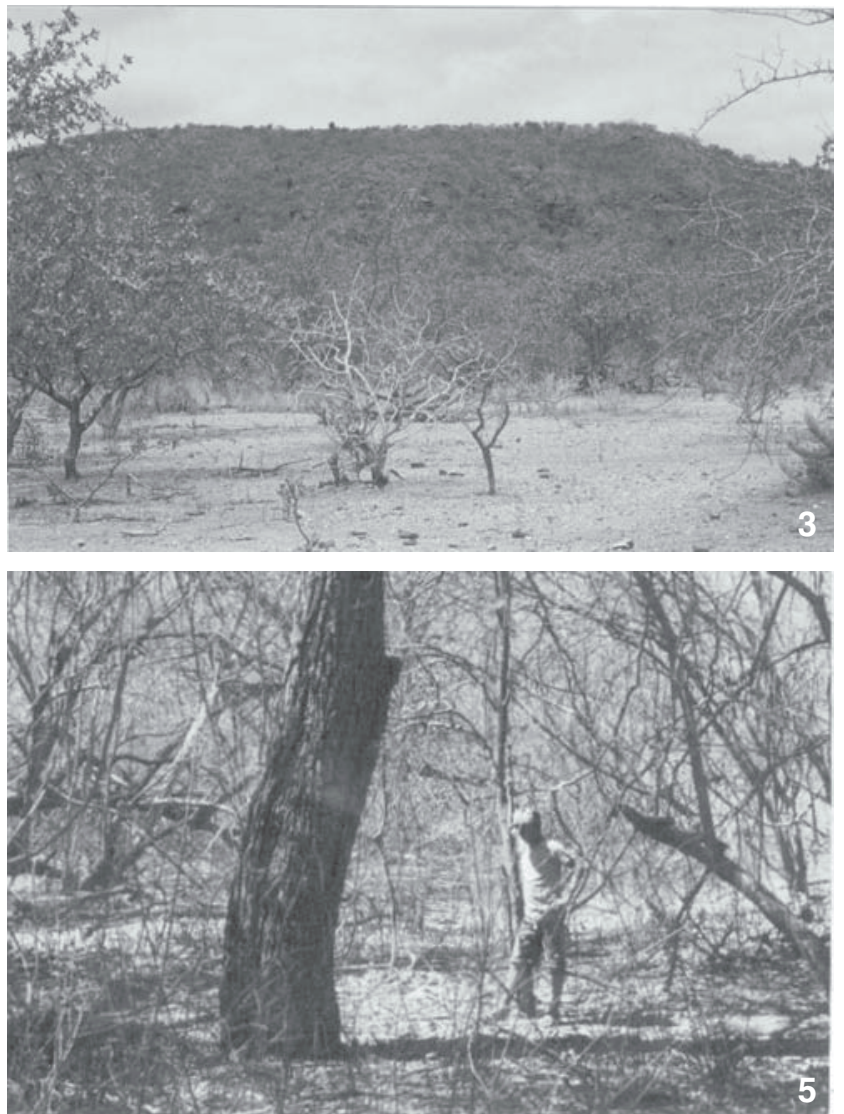
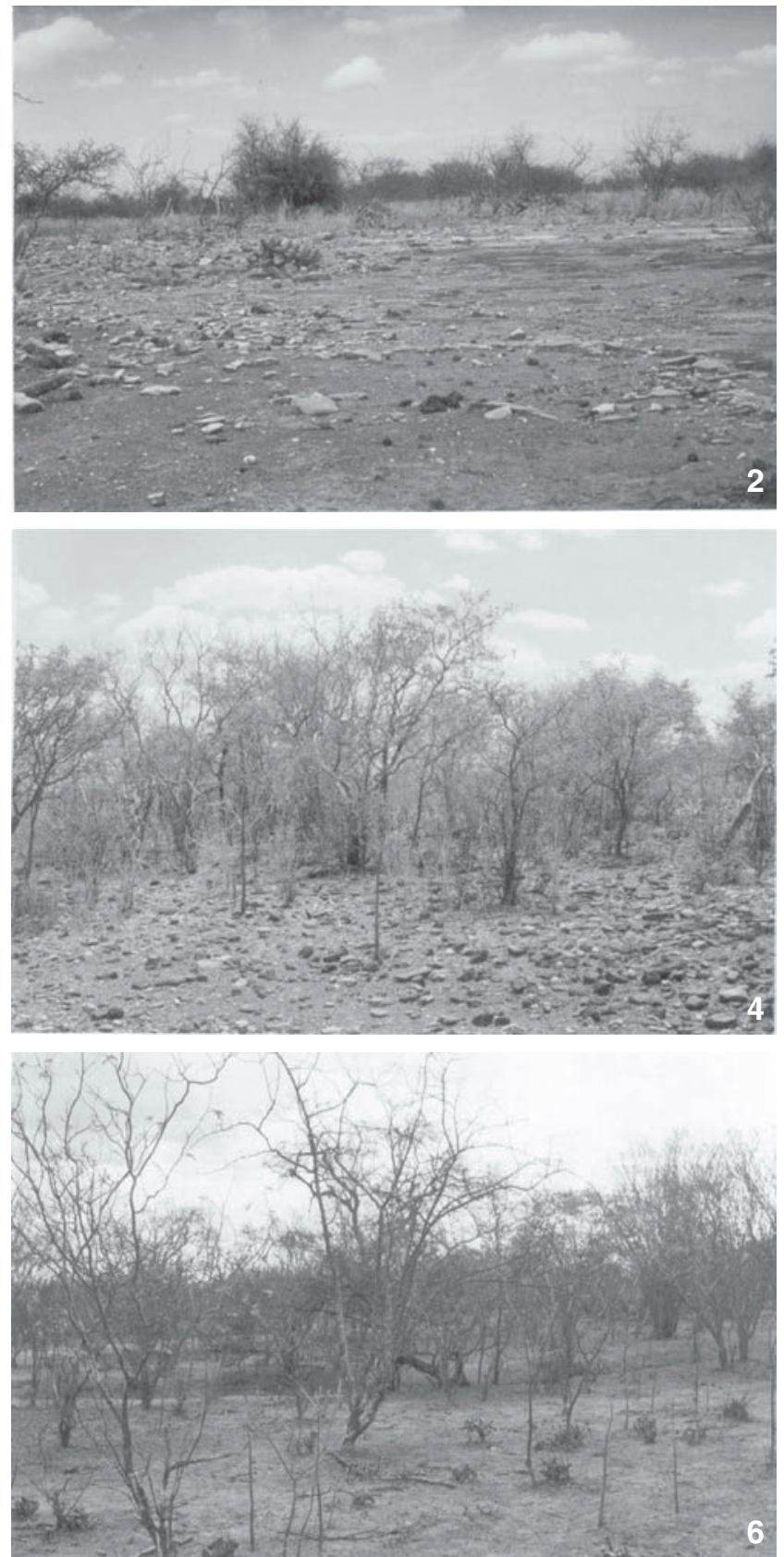

6

Figures 1-6. (1) Location of the Municipality of Curaçá, Bahia, in Brazilian semi-arid Caatinga, where this study was carried on; (2-6) typical naturals habitats in the Caatinga of Curaçá, Bahia, Brazil: (2) Lajeiro; (3) Serra; (4) Tabuleiro; (5) Baixio; (6) Várzea.

mammals trapped was measured (Pesola $100 \mathrm{~g}$ and $300 \mathrm{~g}$ ) and the animals not killed were released in the original habitat after the end of each field campaign.

\section{Habitat structure}

In each trapped area we used 18 sampling stations in the dry season and 18 in the rainy season (only in the dry season in the "lajeiro") distributed randomly in space in order to sample woody plants taller than $1.5 \mathrm{~m}$ by the point-quarter method (Krebs 1999). Individuals sampled were classified in morphospecies based on vegetative (and, when possible, reproductive) characters and their densities were calculated. For each sampled individual, we have recorded height and six binary variables 
(absent/present) related to phenology: flower budding (from the development of the first bud to the opening of the first flower), flower opening (from the opening of the first flower to the falling of the last one), fruit development (from the development of the first fruit to the maturation of the last one), fruit dispersion (from the dispersion of the first fruit to the dispersion of the last one), leave budding (from the development of the fist bud until just before all the leaves have the typical full grown size), and leave fall (from the loss of pigment of the first leave to total deciduousness).

The stations for the sampling of woody plants were used also to characterize the substratum of the habitats studied. A 2 $\mathrm{m}$ diameter circle with center in each sampling station was evaluated in order to quantify the relative contribution of exposed rock, loose gravel, sand, clay, organic soil, herbs, and litter. Values were attributed to each category in adding to sum 100 in each circle.

\section{DATA ANALYSIS}

\section{Comparison among habitats}

The woody vegetation was compared among habitat categories based on: (a) morpho-species richness using total number and number of morpho-species occurring exclusively in the habitat; (b) morpho-species diversity using the diversity index of Shannon-Wiener (KREBS 1999: 444): the absolute values of the indexes were transformed in values ranging from 0 to $100 \%$ based on the minimum and maximum values possible for each community given the numbers of individuals and morpho-species sampled; (c) woody plants density and height using the Kruskal-Wallis one-way analysis of variance (ANOVA) on ranks followed by the all pairwise multiple comparison procedure (Dunn's method) (SigmaStat for Windows, version 2.0); the test for density was performed on the distributions of the distances measured in the quarter-point method (for density); (d) woody plants phenologic state using the test of goodness of fit with the chi-square statistic on frequency data of individuals classified with the value 1 (present) in each habitat for each one of the six binary variables. The theoretical (expected) proportions for each variable were determined dividing the total frequency by the number of habitats, given the identical number of sampled plants per habitat per season; (e) similarity using a cluster analysis (centroid clustering) on the frequency of morpho-species through the chi-square dissimilarity measure for count data (SPSS for Windows, release 8.0.0).

\section{Indirect gradient analysis}

This analysis intends to reveal the theoretical environmental variables associated with gradients of species abundances (Jongman et al. 1995). The matrix of abundances of small mammal species (estimated by their capture success using the complete set of data of the dry and raining seasons) per habitat was centralized and standardized and then reduced through factor analysis using the principal component model (PCA) (SPSS for Windows, release 8.0.0). The PCA analysis was performed ex- tracting factors associated to the latent roots greater than 1.000, using the Anderson-Rubin method, and applying VARIMAX orthogonal rotation, which simplifies structure of the components (Kleibaun et al. 1988: 620). When factor analysis is performed for description of data, and not for hypothesis testing, wide divergences from ideal conditions can be tolerated ( $\mathrm{GAUCH}_{\mathrm{AU}}$ 1982: 137). A biplot was generated whose axes are the first and second principal component (theoretical latent variables). The biplot represents simultaneously habitats (by symbols) and species (by arrows irradiating from the origin). The direction of the arrow shows the direction of higher increase in abundance and its size represents the rate of increasing abundance.

\section{Direct gradient analysis}

This analysis intends to detect which measured environmental variable fit the theoretical latent variables (JONGMAN et al. 1995). The intensity of the correlation between each latent variable (based on the scores generated by the PCA on indirect gradient analysis) and each measured environmental variable was evaluated by the means of the Spearman's coefficient of correlation. The nine primary environmental variables used were: total number of woody plants morpho-species in the habitat (TMS); number of woody plants morpho-species occurring exclusively in the habitat (EMS); percentage of the diversity index of Shannon-Wiener for the woody morpho-species (SW\%), density of woody plants (PLD); mean height of the woody plants (PLH); contribution to the substratum by exposed rock (ROC), by loose gravel (GRA), by sandy, clayey, or organic soil (SOI) and by herbs and litter (H\&L). Additionally, we used secondary environmental variables (ENV1, ENV2, etc.) generated by the reduction of the primary variables per habitat by the means of one PCA analysis similar to the one described above.

\section{RESULTS}

Monthly rainfall values between January 1997 and March 1999 are shown in figure 7 . They show that 1998 was especially dry in the region: there was no precipitation in seven out of nine months from February to October. The rains started in the last month of the first field campaign (November, $116 \mathrm{~mm}$ ). During the second campaign, it rained $247 \mathrm{~mm}$ scattered between December and February. The rainiest month was March (225.5 mm), after the end of the fieldwork.

\section{Comparison among habitats}

The relative contribution of each category of substratum in the five habitats of Curaçá is presented in figure 8. In all the habitats the herbaceous stratum was scant $(<2 \%)$ and the organic soil has varied from 8 to 18\%. "Serra" and "lajeiro" are similar in possessing the highest contribution of exposed rock ( $>25 \%)$ and the lowest contribution of litter $(<25 \%)$. They differ mainly due to the predominance of gravel and sand in the first and clay in the second. "Tabuleiro", "várzea" and "baixio" are similar in presenting high contribution of litter (> 40\%), which was highest in "baixio" (67\%). However, the 


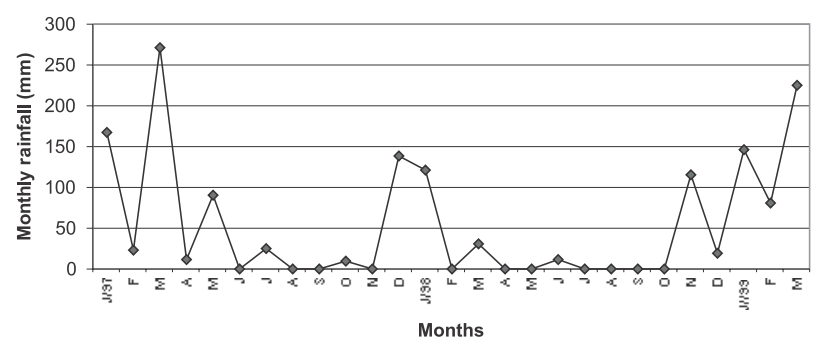

Figure 7. Monthly rainfall values between January 1997 and March 1999 according to the data from the meteorological station LogosButiá, in the vicinities of the sampled Caatinga areas in Curaçá, Bahia, Brazil.

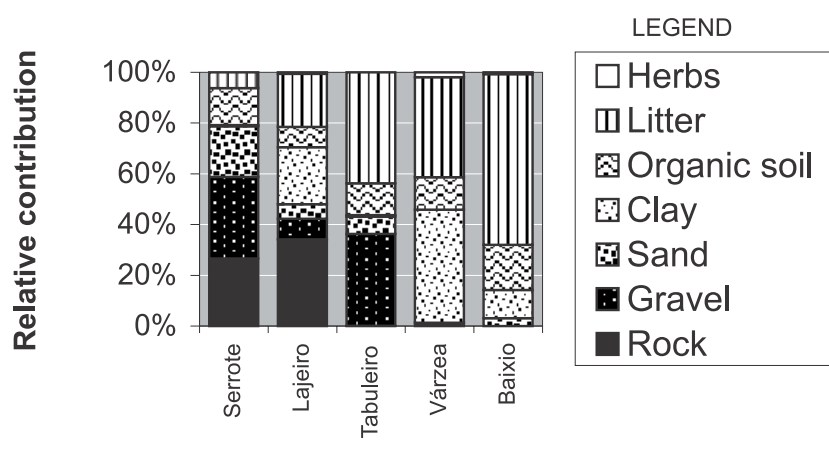

Habitat category

Figure 8. Relative contribution of herbs, litter, organic soil, clay, sand, loose gravel, and exposed rock in the five most representative habitats in the Caatinga of Curaçá, Bahia, Brazil.

soil is clayey in primarily in the "várzea" and secondarily in the "baixio", while the gravel predominates in the "tabuleiro".

The 648 woody individuals analyzed were classified in 36 morpho-species that belong to 14 families (Tab. I). The first and second most abundant morpho-species ("catingueira" and "pereiro") represented 26.6 and $16.2 \%$ of all the sampled plants. The most abundant families were Euphorbiaceae $(33,3 \%)$ and
Leguminosae (31,5\%). Only eight Cactaceae were sampled. The number of morpho-species and families detected by habitat was the highest for "serra" (23 morpho-species, 8 families) and "baixio" $(16 ; 9)$, and the lowest for "tabuleiro" $(9 ; 6)$ (Tab. I). The number of total morpho-species per habitat is highly correlated with the total number of exclusive morpho-species per habitat (Pearson correlation coefficient $=0.967, \mathrm{p}=0.007, \mathrm{~N}=5$ ). The ShannonWiener diversity index has assumed the highest value for the "serra" ( $\mathrm{H}=3,8-84 \%$ of the highest possible value for the community) and the lowest for the "várzea" ( $\mathrm{H}=2.0-59 \%)$ and "lajeiro" ( $\mathrm{H}=2.0-52 \%)$ (Fig. 9). The cluster analysis on the frequencies of morpho-species (Fig. 9) detected a very similar cluster (distance = 1) including "várzea", "tabuleiro", and "baixio". The second cluster includes the first one and lajeiro (distance $=10$ ) and the third one includes all the five habitats (distance $=25$ ).

The plant densities were statistically different among habitats $(H=99.693 ; 4$ DF; $\mathrm{p}<0.001)$ and the Dunn's test detected four groups: "baixio" with the highest values closely followed by "serra", intermediate and homogeneous values for "tabuleiro" and "várzea", and "lajeiro" with the lowest values (Tab. I). The plant heights were also statistically different among habitats (ANOVA: $\mathrm{H}=36.855 ; 4 \mathrm{DF} ; \mathrm{p}<0.001$ ), but the Dunn's test detected overlapping homogeneous groups: one with higher values ("várzea" and "serra"), one with lower values ("tabuleiro", "lajeiro", and "baixio"), and one with intermediate values ("lajeiro", "baixio", and "serra") (Tab. I).

Phenologic state analysis (Tab. II) reveals that: (a) the numbers of woody plants with fruits were always low $(<8 \%)$, except for development in the rainy season (ca. 17\%), and there was no among-habitat difference (P always higher than 0.150); (b) the number of plants with flowers was also low (around 10\%) but there were among-habitat differences for budding (values lower than expected for "baixio" and higher than expected for "lajeiro" in dry season and values higher than expected for "tabuleiro" in rainy season) and opening (values higher than expected for "lajeiro" in dry season and for "várzea" in rainy season) flowers; and (c) falling and budding leaves were observed in both seasons, but the frequency of plants with falling leaves was higher in dry season $(25.6 \times 19.0 \%)$ and the frequency of

Table I. Parameters of plant cover in five natural habitats in the semi-arid Caatinga of Curaçá, Bahia, Brazil. Plant density in individuals. hectare-1; height in meters; (SD) standard deviation; same capital letters represent homogeneous groups in Dunn's multiple comparison test.

\begin{tabular}{|c|c|c|c|c|c|c|}
\hline & Serra & Lajeiro & Baixio & Tabuleiro & Várzea & Total \\
\hline Total number of plant morpho-species & 23 & 13 & 16 & 9 & 10 & 36 \\
\hline Total number of families of plants & 8 & 7 & 9 & 6 & 4 & 14 \\
\hline Number of exclusive plant morpho-species & 10 & 2 & 5 & 2 & 1 & - \\
\hline Woody plants density: Mean \pm SD & $1527 \pm 2.7$ & $150 \pm 0.5$ & $1721 \pm 3.0$ & $652 \pm 1.1$ & $644 \pm 1.1$ & - \\
\hline Anova: $\mathrm{H}=99.693 ; 4 \mathrm{DF} ; \mathrm{p}<0.001$ & B & D & A & C & C & \\
\hline Height Mean ( SD & $3.0 \pm 1.32$ & $2.6 \pm 1.44$ & $2.9 \pm 2.04$ & $2.3 \pm 0.76$ & $3.5 \pm 2.15$ & - \\
\hline Anova: $\mathrm{H}=36.855 ; 4 \mathrm{DF} ; \mathrm{p}<0.001$ & BC & $A B$ & $A B$ & $A$ & C & \\
\hline
\end{tabular}



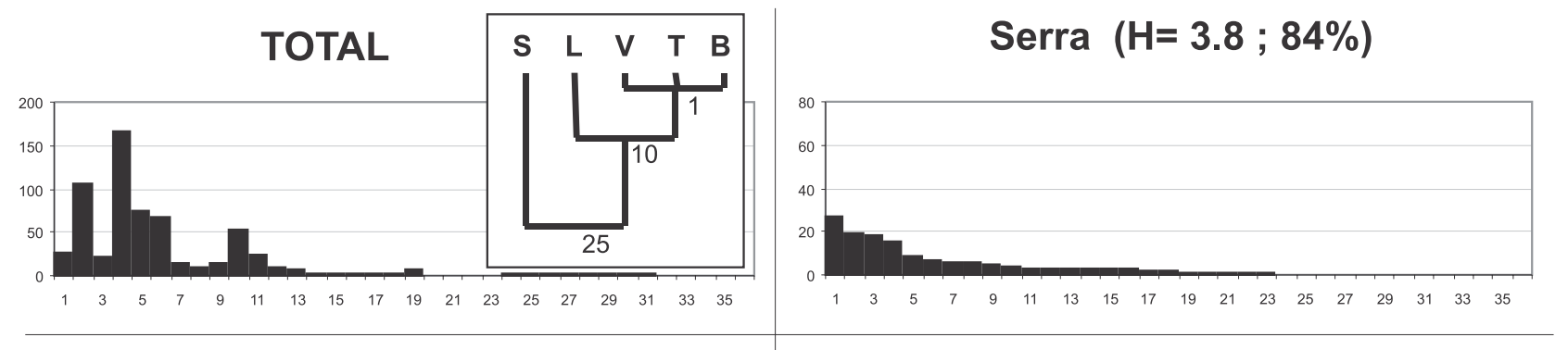

Tabuleiro (2.8 - 68\%)

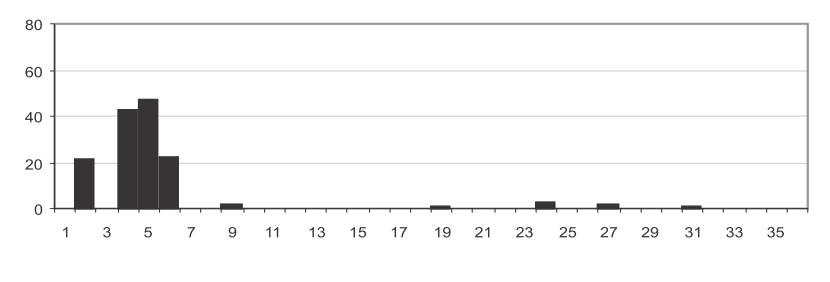

Lajeiro $(2.0 ; 52 \%)$
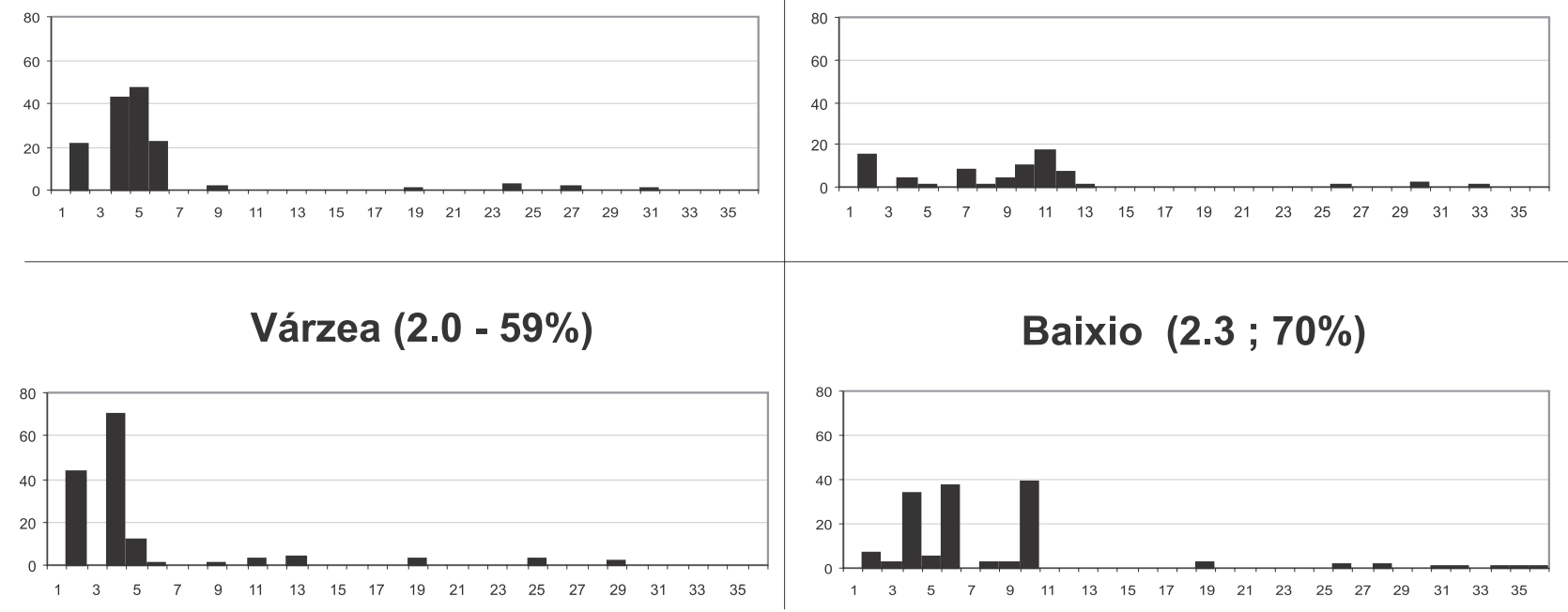

Baixio $(2.3 ; 70 \%)$

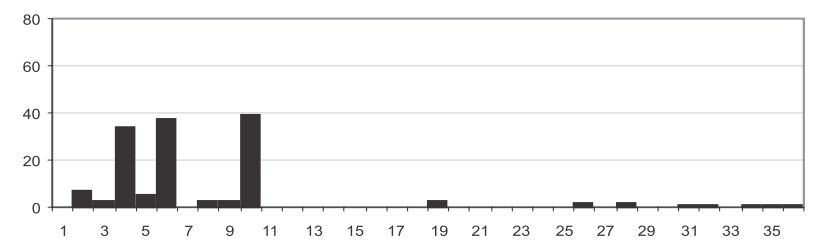

Figure 9. Abundance distribution of woody plant species sampled by the point-quarter method in five representative natural habitats of the semiarid Caatinga of Curaçá, Bahia, Brazil. The sequence of morfo-species is presented in descending order of abundance for the habitat possessing the higher number of morpho-species (Serra). Values in parenthesis represent Shannon-Wiener index of diversity and percentage of the maximum index possible for the community. The dendrogram over the first graphic represents the result of the cluster analysis of the habitats based on the frequency of morpho-species (capital letters = initials of habitats; numbers = measure of dissimilarity).

plants with budding leaves was higher in the rainy season $(58.8$ $\mathrm{x} 37.2 \%)$. Frequency of falling leaves differed among habitats only in the rainy season (more frequent than expected in "várzea" and less frequent both in "serra" and "baixio") and budding leaves differed in both seasons (rainy season: frequency lower than expected in "várzea"; dry season: lower than expected in "serra" and higher in "tabuleiro").

Small mammals

Three species of marsupials (Didelphis albiventris Lund, 1840, Gracilinanus agilis, and Monodelphis domestica) and three species of rodents (Wiedomys pyrrhorhinos, Thrichomys apereoides, and Galea spixii) were captured. The global capture success was $0.56 \%$, ranging from $0.15 \%$ in the "tabuleiro" to $1.50 \%$ in the "lajeiro" (Tab III). Small mammals were captured twice as much during the dry season $(\mathrm{n}=32)$ than during the rainy one $(\mathrm{n}=$ 14) due mainly to capture success in the "serra" and "lajeiro".

The PCA performed for the indirect gradient analysis (matrix of species abundances) has extracted three components (theoretical latent variables) that explain respectively (values before-after rotation): $45.6 \%-31.0 \%, 26.7 \%-30.8 \%$, and $18.4 \%$ $28.9 \%$ of the total data variance. Two biplots were built based on the $1^{\text {st }}$ and $2^{\text {nd }}$ and $1^{\text {st }}$ and $3^{\text {rd }}$ latent variables (Fig. 10). Graphic analysis indicates that abundance gradients of $W$. pyrrhorhinos and $M$. domestica (and less striking Thrichomys apereoides) are highly correlated with the first latent variable; G. spixii and Gracilinanus agilis are highly correlated with the second; and D. albiventris and T. apereoides are highly correlated with the third. Moreover, the first species in each pair is negatively correlated to the latent variable, and the second species, positively. The habitats have high absolute scores in different axes: "lajeiro" score is high and positive on first axis, "várzea" score is high and positive on the second, "baixio" score is high and negative on the third axis, and "serra" score is high and positive in the third axis.

Revista Brasileira de Zoologia 22 (1): 119-129, março 2005 


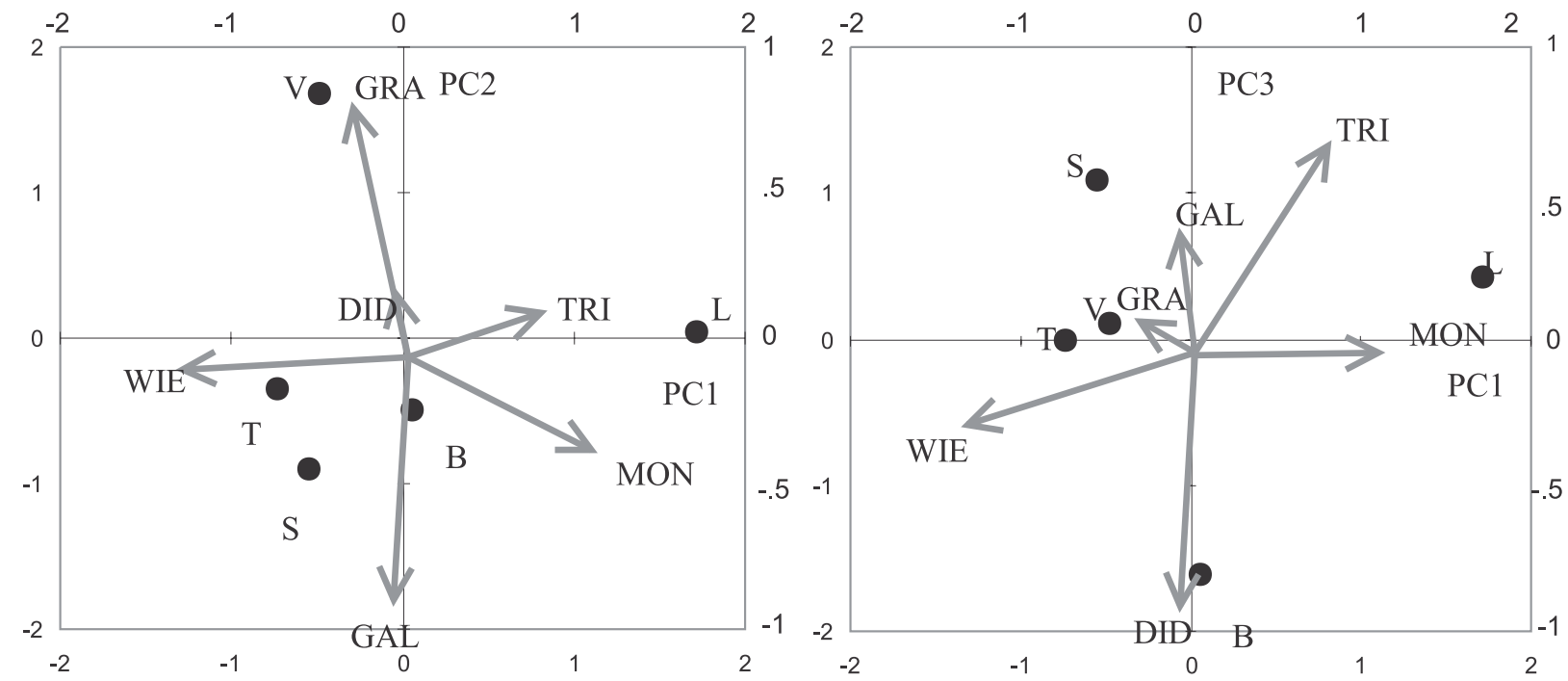

Figure 10. PCA-ordination diagram in correlation biplot scaling with species represented by arrows and habitats by circles for data on the small mammal from the semi-arid Caatinga of Curaçá, Bahia, Brazil. Bottom and left scales applies to habitats and top and right scales applies to species. Species: (DID) Didelphis albiventris, (GAL) Galea spixii, (GRA) Gracilinanus agilis, (MON) Monodelphis americana, (TRI) Thrichomys apereoides, (WIE) Wiedomys pyrrhorhinos; Habitats: (B) baixio, (L) lajeiro, (S) Serra, (T) tabuleiro, (V) várzea.

Table II. Phenologic state of woody plants in five natural habitats in the semi-arid Caatinga of Curaçá, Bahia, Brazil, in the rainy and dry seasons, and results of the comparisons based on the test of goodness of fit. Values marked with $\left(^{*}\right)$ represent the highest contribution to the total $\left(\chi^{2}\right.$ calculated. Number of plants sampled per habitat $=72$. $\left(\chi^{2}=\right.$ chi-square; $p=$ probability. Data for lajeiro in the rainy season were not collected.

\begin{tabular}{|c|c|c|c|c|c|c|c|c|}
\hline & \multirow{2}{*}{ Season } & \multirow{2}{*}{ Expected frequency } & \multicolumn{5}{|c|}{ Observed frequency } & \multirow{2}{*}{ Test results } \\
\hline & & & $S$ & $\mathrm{~L}$ & $T$ & $B$ & $\mathrm{~V}$ & \\
\hline \multirow{2}{*}{ Fruit: development } & Dry & 1.8 & 4 & 1 & 2 & 2 & 0 & $\chi^{2}=4.889 ; p=0.299$ \\
\hline & Rainy & 16.5 & 17 & - & 15 & 21 & 13 & $\chi^{2}=2.121 ; p=0.713$ \\
\hline \multirow{2}{*}{ Fruit: dispersion } & Dry & 6.0 & 8 & 2 & 7 & 7 & 6 & $\chi^{2}=3.667 ; p=0.453$ \\
\hline & Rainy & 4.0 & 1 & - & 4 & 8 & 3 & $\chi^{2}=6.500 ; p=0.165$ \\
\hline \multirow{2}{*}{ Flower: budding } & Dry & 10.4 & 8 & $24^{*}$ & 13 & $0^{*}$ & 7 & $\chi^{2}=30.500 ; p<0.001$ \\
\hline & Rainy & 11.3 & 15 & - & $18^{*}$ & 6 & 6 & $\chi^{2}=10.200 ; p=0.037$ \\
\hline \multirow{2}{*}{ Flower: opening } & Dry & 8.4 & 8 & $18^{*}$ & 10 & $1^{*}$ & 5 & $\chi^{2}=19.190 ; p=0.001$ \\
\hline & Rainy & 12.5 & 6 & - & 13 & 10 & 21 & $\chi^{2}=9.680 ; p=0.046$ \\
\hline \multirow{2}{*}{ Leave: budding } & Dry & 37.2 & $15^{*}$ & 40 & $59^{*}$ & 38 & 34 & $\chi^{2}=26.527 ; p<0.001$ \\
\hline & Rainy & 58.8 & 57 & - & 72 & 70 & $36^{*}$ & $\chi^{2}=14.004 ; p=0.007$ \\
\hline \multirow{2}{*}{ Leave: fall } & Dry & 25.6 & 32 & 24 & 26 & 19 & 27 & $\chi^{2}=3.484 ; p=0.480$ \\
\hline & Rainy & 19.0 & $1^{*}$ & - & 15 & $6^{*}$ & $54^{*}$ & $\chi^{2}=91.263 ; p<0.001$ \\
\hline
\end{tabular}

The PCA performed for the direct gradient analysis (matrix of primary environmental variables) has extracted four components (secondary environmental variables) that explain $100 \%$ of the total data variance (Tab. IV). The first component (ENV1) correspond to a gradient of increasing density, richness, and diversity of woody plants; the second corresponds
(ENV2) to a gradient of increasing rocky substratum and decreasing litter (as H\&L represents mainly the amount of litter given that there is small herbaceous covering in all habitats); the third (ENV3) corresponds to a gradient of increasing soil and woody plants height; and the fourth (ENV4) corresponds to a gradient of contribution of loose gravel in the substratum. 
Table III. Number of small mammals captured and capture success in five natural habitats in the semi-arid Caatinga of Curaçá, Bahia, Brazil, in the rainy and dry seasons. In each cell, the values $X ; Y(Z)$ represent, respectively, number of animals captured in the dry season, in the rainy season, and success of capture (\%); se = sampling effort.

\begin{tabular}{|c|c|c|c|c|c|c|}
\hline Species & $\begin{array}{c}\text { Serra } \\
(\mathrm{se}=3,480)\end{array}$ & $\begin{array}{c}\text { Lajeiro } \\
(\mathrm{se}=333)\end{array}$ & $\begin{array}{l}\text { Tabuleiro } \\
(\mathrm{se}=666)\end{array}$ & $\begin{array}{c}\text { Baixio } \\
(\mathrm{se}=666)\end{array}$ & $\begin{array}{c}\text { Várzea } \\
(\mathrm{se}=3,480)\end{array}$ & $\begin{array}{c}\text { Total } \\
\text { (se }=8,625) \\
\end{array}$ \\
\hline Thrichomys apereoides & $8 ; 2(0.29)$ & $4 ; 0(1.20)$ & - & - & $4 ; 0(0.11)$ & $16 ; 2(0.21)$ \\
\hline Wiedomys pyrrhorhinos & $5 ; 4(0.26)$ & - & $0 ; 1(0.15)$ & $1 ; 0(0.15)$ & $0 ; 5(0.14)$ & $6 ; 10(0.19)$ \\
\hline Galea spixii & $4 ; 0(0.11)$ & - & - & - & - & $4 ; 0(0.05)$ \\
\hline Didelphis albiventris & - & - & - & $0 ; 1(0.15)$ & $3 ; 0(0.09)$ & $3 ; 1(0.05)$ \\
\hline Gracilinanus agilis & $1 ; 0(0.03)$ & - & - & - & $1 ; 1(0.06)$ & $2 ; 1(0.03)$ \\
\hline Monodelphis domestica & - & $1 ; 0(0.30)$ & - & - & - & $1 ; 0(0.01)$ \\
\hline Total & $18 ; 6(0.69)$ & $5 ; 0(1.50)$ & $0 ; 1(0.15)$ & $1 ; 1(0.30)$ & $8 ; 6(0.46)$ & $32 ; 14(0.56)$ \\
\hline
\end{tabular}

The values of Spearman's coefficient correlation of each theoretical latent variable and each primary and secondary environmental variable were computed and they are ranked in figure 11. The first theoretical variable (first axis of indirect gradient PCA) is highly correlated with the secondary variable ENV2 and with H\&L. The second one is highly correlated with the secondary variable ENV1 and with EME, SW\%, and DEN. The third one is highly correlated with the secondary variable ENV4 and with GRA. The primary variables correlated with each theoretical variable have high loadings on the secondary variable correlated with this very theoretical variable. The secondary variable ENV3 is not particularly correlated with any theoretical variable.

\section{DISCUSSION}

Capture success, abundance, and richness of Caatinga small mammals assemblages

The capture success of small mammals in Curaçá was low, ranging one order of magnitude (from $0,15 \%$ to $1,5 \%$ ) in the habitats evaluated. Capture indexes can be used as density estimators given the presumption that differences in trapability are proportional to differences in population densities. Although this might not hold in real situations (e.g. ConRoy 1996), here capture indices will be compared as density data for small mammals are not available in most of studies we cited for discussion of our results.

Streilein has carried on a 15 months long mark-recapture study in the Caatinga near Exu, Pernambuco, obtaining 1351 captures of small mammals after a sampling effort of about 25,000 trap-nights (STREILEIN 1982a, d). The resulting capture success (i.e., 5,40\%) probably overestimates the densities because, although not explicitly cited, the figures presented by the author were seemly calculated including recaptures. In studies carried on by one of us in the Caatinga dunes near the middle São Francisco River (Ibiraba, Bahia, Brazil) the capture success ranged from $0.3 \%$ and no recaptures in moments or areas where plenty fruits were available on the ground to $1.8 \%$ (or $4.1 \%$, for non-
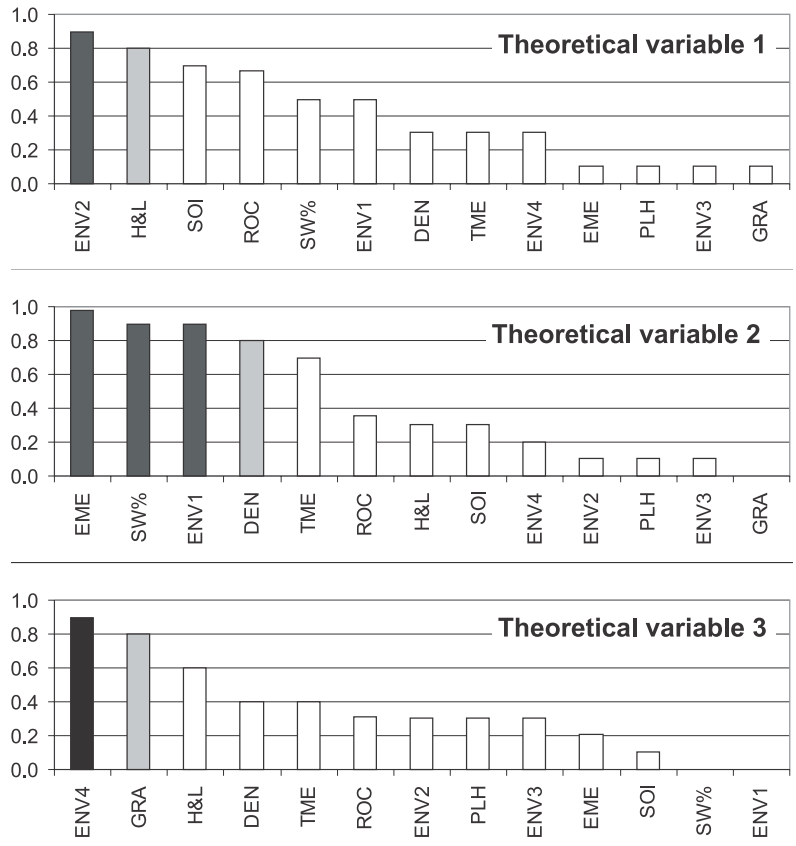

Figure 11. Values of the Spearman's coefficient correlation ( $y$ axis) between each primary and secondary environmental variables $(x$ axis) and each theoretical latent variable derived from the small mammals abundance matrix (each graph). Painted bars represent coefficients associated with relatively small significance values (black: $p \leq 0.05$; gray: $0.05 \leq p \leq 0.10$ ). See text in section Material and Methods or table IV for description of variables.

exhaustive trapping) in moments or areas with low fruit availability (P.L.B. DA ROCHA, unpublished master thesis).

Capture success in Caatinga seems low when compared to values obtained in other open biomes as for humid "campos" in Brazilian Cerrado (3.5\% for exhaustive trapping: BoRCHERT \& HANsen 1983), andean mountains in Patagonia (6.6\% 
Table IV. Results of the PCA analysis (percentage of variance explained before and after rotation and loadings of variables on components) of nine primary environmental variables measured in five natural habitats in the semi-arid Caatinga of Curaçá, Bahia, Brazil.

\begin{tabular}{|c|c|c|c|c|}
\hline & \multicolumn{4}{|c|}{ COMPONENT (secondary environmental variable) } \\
\hline & ENV1 & ENV2 & ENV3 & ENV4 \\
\hline \multicolumn{5}{|l|}{ Variance explained } \\
\hline Before rotation (\%) & 41.5 & 27.7 & 19.2 & 11.6 \\
\hline After rotation $(\%)$ & 38.3 & 24.3 & 19.4 & 18.0 \\
\hline \multicolumn{5}{|l|}{ Primary environmental variable } \\
\hline DEN- Density of woody plants & 0.937 & $(0.125)$ & 0.045 & $(0.322)$ \\
\hline EME- Number of exclusive plant morpho-species & 0.936 & 0.177 & $(0.017)$ & 0.305 \\
\hline SW\%- Percent. of Shannon-Wiener diversity index & 0.895 & 0.434 & 0.020 & $(0.105)$ \\
\hline TME- Total number of plant morpho-species & 0.887 & $(0.070)$ & 0.084 & 0.449 \\
\hline H\&L- Contribution of herbs and litter & 0.023 & $(0.954)$ & $(0.076)$ & $(0.288)$ \\
\hline ROC- Contribution of exposed rock & 0.243 & 0.928 & $(0.268)$ & $(0.092)$ \\
\hline PLH- Mean height of woody plants & 0.174 & $(0.325)$ & 0.930 & 0.004 \\
\hline SOI- Contribution of sandy, clayey, and organic soil & $(0.095)$ & 0.199 & 0.856 & $(0.467)$ \\
\hline GRA- Contribution of loose gravel & 0.074 & 0.175 & $(0.253)$ & 0.949 \\
\hline
\end{tabular}

for exhaustive trapping: CANTONI et al. 2001), and semi-arid areas in Australia (4.4\% for non-exhaustive trapping: CARTHEWSusAn \& Keynes 2000). However, figures as low as the suggested by Mares and colleagues (1985: 65) citing STREILEIN (1982c: 267) for Caatinga areas (only one small mammal trapped after a 29,000 trap-nights effort) can lead the reader to a wrong picture of the biome: as Streilein paper cites this value referring to only one species, and not to the entire community, the capture success presented $(0.003 \%$, and not $0.00003 \%$ as wrongly quoted in Streilein text) is not comparable to values usually presented in community studies. Moreover, in forested areas from Neotropics capture success can be as low as those found in Caatinga, as for Amazonian Forest areas in French Guyana (0.5 to $2.0 \%$ for exhaustive trapping: GulLlotin 1982) and Trinidad (1.3 to $3.5 \%$ for exhaustive trapping: EvERARD \& TiKasingH 1973) and Atlantic Forest areas in South of Bahia (1.5 to 5.1\% for exhaustive trapping in the interior of continuous forest: R. PARDINI, unpublished doctoral thesys). Consequently, the perception that small mammal fauna in Caatinga is uniquely marked by scarcity (MAREs et al. 1985) probably should be reviewed.

On the other hand, the local species richness in many tropical forest small mammal assemblages is usually higher than in Caatinga. In most municipalities inside the limits of the biome Caatinga, the number of marsupials recorded is near four, and in some municipalities as much as 11 species of the family Muridae alone are recorded (Oliveira et al. 2003). However, the authors do not inform if they represent syntopic species. The present study has detected six species in Curaçá (3 rodents and 3 marsupials) and additionally Kerodon rupestris (Wied-Neuwied, 1820) (not trapped but present in the area). Another study in Caatinga near Exu, based on a sampling effort three-folds higher, has detected four additional Sigmodon- tinae species (Streilein 1982a). The higher richness could be attributed to: (a) higher sampling effort leading to detection of rare species, (b) the proximity of the area to Chapada do Araripe, a mesic topographic enclave harboring a fauna more typical from Cerrado, and (c) the presence of agricultural fields near the collecting area, favoring the presence of three of the additional species. For areas in Amazonian Forest there are records of richer communities composed of more than 12 species (e.g. Panama, 12 species: Fleming 1971; Trinidad, 15 species: Everard \& Tikasingh 1973; French Guyana, 16 species: Guillotin 1982). Even though, one study carried on in the Atlantic Forest has detected from 6 to 12 sympatric species (PARDINI, op. cit.), similar to the richness we found in Caatinga.

\section{Small mammal electivities for Caatinga habitats}

Mares and colleagues propositions about the influences of the habitat on the abundance of small mammals can be abstracted as follows: Caatinga habitats can be classified as outcropping and non-outcropping habitats. This categorization is based on the structural complexity of the substratum that would be positively correlated with the ability to retain moisture and the amount of shelter offered to the fauna. Both features would be limiting factors to the survival of small mammals (Caviomorpha rodents and marsupials, but not Sigmodontinae rodents) and would limit their abundances, mainly because these animals would not be physiologically able to deal with the water stress imposed by the Caatinga climate (Lacher 1981, Streilein 1982b, c, d, Mares et al. 1985).

On one hand, this picture has some limitations. Firstly, comparative primary data on abundance of small mammals are restricted to the mark-recapture study by STREILEIN (1982a) developed on a 2.7 hectares area that includes as outcropping habi- 
tats only "lajeiro" and as non-outcropping habitats only "Caatinga Baixa" (low thorn scrub) and old agricultural field. This represents an incomplete sampling of Caatinga habitats and it is insufficient to support a general model for small mammal abundances. Secondly, although the amount of potential shelter in different habitats could be easily evaluated by direct observation, comparative microclimatic data and resources availability (e.g., fruits and seeds, arthropods) were never quantified in a way that allowed informed comparison. Humidity was assumed to be higher in outcropping habitats based on floristic parameters of "serras" only (MAREs et al. 1981: 89) although small mammal abundance data were never collected for this habitat.

On the other hand, the predictions based on picture developed by Mares and colleagues are not corroborated by the present study. Firstly, the amount of available shelter (as described in section Material and Methods) seems not to be positively correlated with the capture success along the habitats for W. pyrrhorhinos, D. albiventris and Gracilinanus agilis; moreover, four out of five species for which we collected more than one specimens were relatively abundant in the "várzea", the poorest habitat in shelter availability.

Secondly, indirect measurements of quality habitat for small mammal species, namely the amount of fruits (food availability) and budding or falling leaves (water availability), do not fit the prediction that outcropping habitats are better suited for the fauna. Additionally, although "várzea" is subject to flooding, and therefore possibly also humid, during the year studied it has been completely dry and humidity could not be used as an argument for high capture success.

Thirdly, the abundances of Caviomorph rodents and marsupials are not positively correlated with the amount of outcropping substratum. If we consider that each one of the five areas analyzed in Curaçá are representative of the main five habitats, and that five habitats are representative of the diversity of local Caatinga physiognomies, it is possible to say that three theoretical gradients (the ones resultants from the indirect gradient analysis) are the main underlying factors influencing the abundances of local small mammal species. Each one of them has a high positive influence on the abundance of one species and a high negatively influence on the abundance of another one. Also each theoretical gradient is highly correlated with one of the four secondary environmental variables derived from the PCA analysis. Therefore, the first theoretical variable is highly and positively correlated with the second environmental gradient, which represents an increase of rocky substratum and decrease of litter. Abundances of Wiedomys pyrrhorhinos decrease and abundances of Monodelphis domestica (and, more lightly, Thrichomys apereoides) increase along this gradient. Although this environmental gradient represents about $25 \%$ of the total environmental variance measured in Curaçá, it seemly does not affect abundances of the most conspicuous species of Caviomorph rodents and marsupials, as predicted by Mares and colleagues. In fact, it strongly influences only one Sigmodontinae species and in a negative way.

The second theoretical variable is highly and positively correlated with the first environmental gradient, which represents an increase of richness, diversity, and density of woody plants. Abundance of Galea spixii decreases and abundance of Gracilinanus agilis increases along this gradient suggesting that both the Caviomorph rodent and marsupial species are affected not by outcroppings but by vegetation features.

The third theoretical variable is highly and positively correlated with the fourth environmental gradient, which represents an increase in amount of loose gravel. Abundances of Didelphis albiventris decrease and abundances of Thrichomys apereoides increase along this gradient. Again, both Caviomorph and marsupial species are affected not by the outcroppings but by the amount of gravel.

The present study is based on a small sampling effort for the small mammals in the Caatinga and, as the capture success in this biome is not high, we encourage other studies like this one to corroborate or refute our conclusions. Based on our data and arguments, the causal factors underlying the pattern of small mammal abundances in the Caatinga seem to be more complex than previously supposed, including variables other than structural complexity of the substratum and humidity and shelter availability. This result should encourage further detailed studies on the physiological abilities of Caatinga small mammals to deal with stressing habitats. Recent studies suggest that Wiedomys pyrrhorhinos can be able to deal with water scarcity (Ribeiro et al. 2004), that physiological parameters of Thrichomys apereoides can present a wide geographical variability (Mendes et al. 2004) and that one endemic species from the Caatinga in the middle Rio São Francisco Dunes can save energy by lowering its temperature in some circumstances (BARRos et al. 1998). These physiological derived traits do not reveal the extreme pattern of adaptation seem in some paradigmatic desert small mammals (e.g., Dipodomys merriani, Jaculus jaculus, Psamomys obesus, Notomys alexis; Schmidt-Nielsen 1979, Degen 1997). However, it can be interpreted either as small degree of adaptation in the Caatinga fauna or as a naïve paradigm, as small modifications in different physiological and behavioral systems could prepare small mammals to live in stressful habitats.

Additionally the recurrent pattern of two species (one rodent and one marsupial) being influenced, one positively and one negatively, by each theoretical variable suggests also that the pattern of use of habitat resource could result from contemporary or past competition. Again, new ecological studies based both on manipulative and phylogenetic methods are encouraged to test this hypothesis.

\section{ACKNOWLEDGEMENTS}

We are indebt with Dr. Elisabeth Spinelli de Oliveira (FFCL-USP) for borrowing the live traps used in the present study, and with Msc. Jorge José Cherem for confirming the 
identification of the small mammal species. Small mammals capture was performed under the approval of licenses (IBAMA 097/97-DIFAS and 128/98-DIFAS). We are also indebt to the personal of the Projeto Ararinha-Azul (Yara de Melo Barros and her equip) and to the local inhabitants from Curaçá for the help in the fieldwork. The project has received financial support from Fundación Loro Parque and IBAMA.

\section{REFERENCES}

Ав'SABER, A.N. 1980. O domínio morfoclimático das caatingas brasileiras. Craton \& Intracraton Escritos e Documentos, São José do Rio Preto, 6: 1-35.

Barros, R.C.H.; E.S. Oliveira; P.L.B. Da Rocha \& L.G.S. Branco. 1998. Respiratory and metabolic responses of the spiny rats Proechimys yonenagae and $P$. iheringi to $\mathrm{CO}_{2}$. Respiration physiology, Berlin, 111: 223-231.

BORCHERT, M. \& R.L. HANSEN. 1983. Effects of flooding and wildfire on valley side wet campo rodents in central Brazil. Revista Brasileira de Biologia, Rio de Janeiro, 43 (3): 229-240.

Cantoni, G.; P. Padula; G. Calderon; J. Mills; E. Herrero; P. Sandoval; V. Martinez; N. Pini \& E. Larrieu. 2001. Seasonal variation in prevalence of antibody to hantaviruses in rodents from southern Argentina. Tropical Medicine and InternationalHealth, London, 6 (10): 811-816.

Carthew-Susan, M. \& T. Keynes. 2000. Small mammals in a semiarid community, with particular reference to Ningaui yvonneae. Australian Mammalogy, Sydney, 22 (2): 103-109.

Conroy, M.J. 1996. Techniques for estimating abundance and species richeness: abundance indices, p. 179-192. In: D.E. Wilson; F.R., Cole; J.D. Nichols; R. Rudran \& M.S. Foster (Eds). Measuring and monitoring biological diversity: standard methods for mammals. Washington, Smithsonian Institution Press, 409p.

Degen, A.A. 1997. Ecophysiology of small desert mammals. Berlin, Springer Verlag, 296p.

Everard, C.O.R. \& E.S. Tikasingh. 1973. Ecology of the rodents, Proechimys guyannensis trinitatis and Oryzomys capito velutinus, on Trinidad. Journal of Mammalogy, Greensboro, 54 (4): 875-886.

FLeming, T.H. 1971. Population ecology of three species of neotropica rodents. Miscelaneous Publications Museum of Zoology, Michigan, 143: 1-77.

GaUCH, H.G. 1982. Multivariate analysis in ecology. London, Cambridge University Press, 297p.

Guillotin, M. 1982. Place de Proechimys cuvieru (Rodentias: Echimyidae) dans les peuplements micromammaliens terrestres de la forêt guyanaise. Mammalia, Paris, 46 (3): 299-318.

Jongman, R.H.G.; C.J.F. Ter BraAk \& O.F.R. van Tongeren. 1995. Data analysis in community and landscape ecology. London, Cambridge University Press, 299p.

Kleibaun, D.G.; L.L. Kupper \& K.E. Muller. 1988. Applied regression analysis and other multivariate methods. Boston,
PWS-KENT Publishing Company, 718p.

KreBs, C.J. 1999. Ecological methodology. New York, Addison Wesley Logman, $2^{\text {nd }}$ ed., $620 p$.

LACHER JR., T.E. 1981. The comparative social behavior of Kerodon rupestris and Cavia spixii and the evolution of behavior in the Caviidae. Bulletin of Carnegie Museum of Natural History, Pittsburgh, 17: 1-71.

Mares, M.A.; M.R.Willig; K.E. Steilein \& T.E. Lacher Jr. 1981. The mammals of northeastern Brazil: a preliminary assessment. Annals of Carnegie Museum, Pittsburgh, 50: 81-137.

Mares, M.A.; M.R. Willig \& T.E. LaCher Jr. 1985. The Brazilian Caatinga in South American zoogeography: tropical mammals in a dry region. Journal of Biogeography, Oxford, 12: 57-69.

Mendes, L.A.F.; P.L.B. Rocha; M.F.S. Ribeiro; S.F. Perry; E.S. OliVEIRA. 2004. Differences in ingestive balance of two populations of neotropical Thrichomys apereoides (Rodentia, Echimyidae). Comparative Biochemistry and Physiology, Part A, Vancouver, 138: 327-332.

Oliveira, J.A.; P.R.Gonçalves; C.R. Bonvicino. 2003. Mamíferos da Caatinga, p.275-302. In: I.R. Leal; M. Tabarelli \& J.M.C. DA SILVA (Eds). Ecologia e conservação da Caatinga. Recife, Ed. Universitária da UFPE, 822p.

Ribeiro, M.F.S.; P.L.B. Rocha; L.A.F. Mendes, S.F. Perry \& E.S. OliVEIRA. 2004. Physiological effects of the short-term water deprivation in the black-footed pygmy rice rat (Oligoryzomys nigripes) and the South American water rat (Nectomys quamipes) within a phylogenetic context. Canadian Journal of Zoology, Ottawa, 82: 1-10.

Rızzinı, C.T. 1979. Tratado de Fitogeografia do Brasil. São Paulo, EDUSP, vol. 2, 374p.

Schmidt-Nielsen, K. 1979. Desert animals: physiological problems of heat and water. New York, Dover Publications, 277p.

Streilein, K.E. 1982a. Ecology of small mammals in the semiarid Brazilian Caatinga. I. Climate and faunal composition. Annals of Carnegie Museum, Pittsburgh, 51: 79-107.

Streilein, K.E. 1982b. Ecology of small mammals in the semiarid Brazilian Caatinga. II. Water relations. Annals of Carnegie Museum, Pittsburgh, 51: 109-126.

Streilein, K.E. 1982c. Ecology of small mammals in the semiarid Brazilian Caatinga. III. Reproductive biology and population ecology. Annals of Carnegie Museum, Pittsburgh, 51: 251269.

Streilein, K.E. 1982d. Ecology of small mammals in the semiarid Brazilian Caatinga.IV. Habitat selection. Annals of Carnegie Museum, Pittsburgh, 51: 331-343.

Streilein, K.E. 1982e. Ecology of small mammals in the semiarid Brazilian Caatinga.V. Agonistic behavior and overview. Annals of Carnegie Museum, Pittsburgh, 51: 345-369.

Vanzolini, P.E.; A.M.M. Ramos-Costa \& L.J. VitT. 1980. Répteis das caatingas. Rio de Janeiro, Academia Brasileira de Ciências, 161p.

Received in 01.VII.2004; accepted in 21.I.2005. 